\title{
THE WORLDWIDE DIFFUSION OF THE GLOBAL REPORTING \\ INITIATIVE: WHAT IS THE POINT?
}

\begin{abstract}
This study analyzes the worldwide diffusion of the Global Reporting Initiative (GRI) from the viewpoint of both a macro- and a microanalysis using data from the first decade of this century. For the macroanalysis, logistic curves were used to demonstrate the different stages and patterns in the dissemination of GRI in the different regions of the world that were examined. For the microanalysis, two indices-instability and concentration — were used to analyze and assess GRI diffusion across different sectors of activity. The findings are thus of considerable importance to the understanding of sustainability reporting worldwide. Moreover, they point to probable trends in sustainability reporting over the next few years.
\end{abstract}

Keywords: Sustainability reporting, diffusion, corporate social responsibility, Global Reporting Initiative. 


\section{INTRODUCTION}

During the past three decades, corporate social responsibility (CSR) standards have increased in number and popularity. In a compilation study and literature review conducted earlier this decade, Ligteringen and Zadek (2005) identified more than 300 global corporate standards, each with its own history and criteria. These standards include the United Nations (UN) Global Compact, the Organization for Economic Co-operation and Development's (OECD) directory for multinational enterprises, ISO 14001, the Global Reporting Initiative (GRI), Sullivan's Global Principles, SA 8000, Series AA1000 and ISO 26000. These standards encourage corporate responsibility regarding environmental and social issues. Koerber (2010) states that some degree of overlap can be detected among these standards even though each set of standards is designed to satisfy the specific needs of a stakeholder group.

To provide a broadly applicable and reliable set of standards to the market, corporations worldwide have adopted sustainability reporting (SR) (Lozano and Huisingh 2011) in response to financial scandals and the ongoing economic crisis. These economic troubles have created a climate of uncertainty in the market; investors and shareholders who are making decisions not only require access to financial information, but also to information about environmental and social behavior (Skouloudis et al. 2009). Society is also demanding more transparency in firm operation (Melé et al. 2006; Cornelius et al. 2007). SR appears to meet this demand because the reports are intended to include non-financial information. In light of the paramount necessity to establish a dialogue among all stakeholders, it is crucial to provide information about a company's sustainable development beyond what is provided in its financial report (Krajnc and Glavic 2005; Gilbert and Rache 2007). 
Although the main management system diffusion models, such as ISO 9001, ISO 14001 and some national standards, have been widely studied (Franceschini et al. 2004; Marimon et al. 2006; Casadesus et al. 2008; Marimon et al. 2010; Casadesus et al. 2010; Delmas and Montes-Sancho 2010; Llach et al. 2011), the diffusion of SR initiatives such as the GRI has not yet been investigated.

the GRI presents a strong compromise regarding environmental issues. ISO (2010a) stated that environmental responsibility is a precondition for the survival and prosperity of human welfare. Environmental issues are linked to other social responsibility core subjects and issues that are fundamental in promoting the development of sustainable societies and lifestyles. Because of this fundamental link, the GRI offers a guide to incorporate sustainability development using a firm's indicators of environmental performance. Thus, GRI reporting (2011) has incorporated in its environmental section ten new indicators regarding efficiency improvements, future plans for managing impacts on biodiversity and initiatives to reduce greenhouse gas emissions. Specifically, the G3.1 guide of the GRI (2011) now includes an indicator of cleaner production (EN30) that identifies prevention and environmental management costs based on expenditures related to the following items: extra expenditures to install cleaner technologies (e.g., additional costs beyond those associated with the standard technologies) and extra expenditures on green purchases.

The GRI standard has been selected for analysis in the present study for three reasons.

First, the GRI is the most widely used worldwide standard for sustainability reporting according to a number of researchers (e.g., Skouloudis et al. 2009; Prado-Lorenzo et al. 2009; Tsang et al. 2009; Brown, et al. 2009a; Rasche 2009; Levy et al. 2010).

Second, Manetti (2011) found that the GRI represents the best option available for SR given that it is based on foundations that consider economic, environmental and social 
dimensions. Moreover, Prado-Lorenzo et al. (2009) stated that the GRI presents "a harmonized, standardized, understandable and objective report for all firms worldwide" and that "there is an obligation for certain information to be expressed numerically and monetarily so as to facilitate its comparison."

Finally, according to Berman et al. (2003), the GRI is, after the ISO 14001 standard, the second most influential standard regarding social responsibility; therefore, the GRI and ISO 14001 may follow similar diffusion patterns. Two reasons for this possible similarity are supported by previous research. First, both standards follow the same approach (Reynolds and Yuthas 2008). Second, a high correlation between ISO 14001 implementation and GRI adoption has been found (Mitchell and Hill 2009) because ISO 14001 is used as an information source in GRI reporting.

This study contributes to the extant research in three ways. First, this study increases the understanding of the diffusion of the GRI. Second, this study provides an exploratory descriptive analysis of GRI diffusion worldwide in both macro- and microanalyses. Finally, this study identifies future trends in GRI diffusion.

This work has three main objectives. First, a macrolevel analysis will be developed to explain and predict the diffusion of the GRI on a worldwide scale. Second, GRI diffusion among the main continents will be compared and analyzed to identify different patterns. Finally, an exploratory analysis will be conducted to describe the worldwide state of GRI diffusion through a microlevel analysis of sector levels.

Pursuant to these objectives, the remainder of the paper is organized as follows. The second section provides a review of the literature and a description of the working model. The methodology employed and the statistical results are explained in the third section. The conclusions are presented in the fourth section. 


\section{LITERATURE REVIEW}

\subsection{Sustainability Reporting and Environmental Performance}

O'Connor and Spangenberg (2008) mentioned that the emerging profile of Corporate Social Responsibility (CSR) places distinct requirements on company management. Notably, CSR demands that management address a Triple Bottom Line of economic, social and environmental performance.

To illustrate the different standards related to the disclosure of environmental, social and ethical issues, Table 1 shows a brief classification of corporate responsibility standards in regulatory structures, guidelines and administrative systems based on Koerber (2010).

[Table 1 here]

ISO 14001 is the most adopted environmental management system worldwide (ISO 2007; 2010b; Marimon et al. 2010; 2011), and it is the main source for sustainability reporting disclosure (Mitchell and Hill, 2009). The GRI and ISO 26000 are mainly used to reveal CSR issues. However, the two standards differ. The GRI guide suggests ways in which a company can show what it is doing, while ISO 26000 presents guidance for a firm's integration of social and environmental issues. To ensure that more environmentally and socially responsible decisions are made, decision-makers require tools that facilitate a more complete understanding of the potential impacts. From a social perspective, Asif et al. (2011) consider that the implementation and practice of CSR principles are key indicators for measuring society's and stakeholders' expectations. Following this reasoning, Ciliberti (2011) provides a comprehensive ethics perspective on CSR and mentions some examples of ethics codes that contribute to expanding a firm's CSR strategies. These ethics codes include the Business Social Compliance Initiative and Ethical Trading Initiative for Labor Conditions, the International Chamber of Commerce Guidance on Supply Chain Responsibility, Responsible Care by the International Council 
of Chemical Associations for Health, and the Safety and Environmental Impact of Chemical Products and Processes.

Likewise, Clarkson et al. (2011) argued that recent studies have documented a consistent and significant relationship between information voluntarily disclosed in the GRI and environmental performance. These relationships have been studied from two conceptual frameworks - the socio-political perspective and the voluntary disclosure theory-and have reached opposing conclusions.

The first and older of these frameworks, the socio-political perspective, predicts a negative relationship between environmental performance and voluntary environmental disclosure (Ingram and Frazier 1980; Freedman and Wasley 1990). Thus, Ingram and Frazier (1980) found no association between environmental disclosure and environmental performance. Freedman and Wasley (1990), using the CEP rankings and the Wiseman (1982) index, concluded that environmental disclosures are not indicative of a firm's environmental performance, but these studies did not use GRI reporting.

On the other hand, based on recent studies, the second and newer framework argued that the voluntary disclosure theory predicts a positive association between environmental performance and voluntary environmental disclosures. For example, the studies of Clarkson et al. (2008) and Clarkson et al. (2011) argue that firms with superior environmental performance have more incentives to communicate environmental disclosures than smaller firms have. The 2008 study by Clarkson et al. focuses exclusively on the voluntary environmental disclosures of 191 US firms using GRI guidelines and using the TRI (Toxic Release Inventory) to evaluate environmental performance. The study found that firms with better environmental performance are more forthcoming in truly discretionary disclosure channels. In a more recent study, Clarkson et al. (2011) 
studied how the level and nature of environmental information and environmental performance were related in 51 Australian firms during 2002 and 2006. These authors documented a positive relationship between environmental performance as measured by the level of emissions and by the environmental disclosures of their sample firms. Notably, these studies use GRI guidelines in formatting the disclosure of environmental information, and the findings are consistent with the voluntary disclosure theory.

\subsection{The Importance of the Global Reporting Initiative}

Prado-Lorenzo et al. (2009) stated that sustainability reporting (i) reflects a company's strategic plan to communicate to stakeholders the company's social and environmental performance, (ii) provides a useful framework from which to evaluate the firm and (iii) represents a reliable public source of information and knowledge.

As aforementioned, GRI reporting is the most widely known set of voluntary guidelines for corporate sustainability reporting (Roca and Searcy 2012; Moneva et al. 2006; Brown et al. 2009b) and is still the sole global framework on which companies can base their CR reports (CRRA, 2011). Moreover, considering performance by the rate of uptake, comprehensiveness, visibility, and prestige, the GRI has been amazingly successful since its modest inception in 1999 (Brown et al. 2009a). CRRA (2011) did criticize the GRI, however, noting that the growth rate of GRI reports has developed at a slow but steady pace. GRI reports now approach forty percent of all profiled CR reports.

Companies that have adopted the GRI have aligned their CSR strategies with improving human rights as well as labor, environmental and anticorruption practices (Perez-Batres 2010). The GRI is also a dominant player in spreading social reporting and the specific language, concepts and assumptions of the GRI (Brown et al. 2009a).

Prado-Lorenzo et al. (2009) asserted that the GRI requires the reporting of information on economic, environmental and social issues regardless of whether this information 
reflects negatively on the company. Consistent with this reasoning, Schadewitz and Niskala (2010) stated that the GRI is one of the most important communication tools for decreasing information asymmetry between a firm and its investors and other stakeholders. Therefore, the GRI should provide a more precise valuation of a company while serving as a key driver in helping companies become more sustainable (Lozano and Huising 2011).

\subsection{The Basis of the GRI}

The GRI was created in 1997 under the initiative of the North American Coalition for Environmentally Responsible Economies (CERES) of Boston and the Tellus Institute. In 1999, the United Nations Environment Program (UNEP) joined as a partner to ensure an international perspective.

The purpose of the GRI is to enable the diffusion of sustainability records. Its objective is to provide information guidelines to present a clearer vision of the human and ecological impacts of an enterprise. In addition, one of the GRI's main functions is to enable shareholders and other stakeholders to make well-informed decisions regarding investments and the purchasing of goods and services from the company. The ultimate objective of the guidelines is to create reports that complement-rather than substitute for-companies' other reports, such as their financial reports. Thus, the GRI is a framework from which to judge records of sustainability. Furthermore, the GRI framework provides the opportunity to compare information and conduct benchmarking among the different organizations involved. Thus, the performance indicators of the GRI are directly related to each of the principles of the Global Compact $^{1}$ as reflected in its

\footnotetext{
${ }^{1}$ The UN Global Compact is a strategic policy initiative for businesses that are committed to aligning their operations and strategies with ten universally accepted principles in the areas of human rights, labor, the environment and anticorruption activity. The Global Compact, put forward by Kofi Annan (Secretary-
} 
various content sections: economic aspects, environmental impacts, labor practices, human rights, social aspects and product responsibility.

GRI reports contain information related to the economic, environmental and social aspects of a company. This approach, known as the Triple Bottom Line (GRI 2006), considers more than the bottom line; it incorporates the three "p's" (people, planet and profit). Based on the idea that a company's overall performance can be measured in terms of that entity's contribution to economic prosperity, environmental quality and capital, the triple bottom line provides a framework from which to measure and report an entity's results according to economic, social and environmental parameters.

Three guides published by the GRI in 2000, 2002 and 2006 provide basic guidelines for enterprises to follow when producing a sustainability report. This study is based on the 2006 GRI, which includes substantial changes from earlier versions in guidelines regarding gender, human rights and community impact.

The GRI framework describes both the general content and the sector-specific content that had been agreed upon by a wide range of stakeholders worldwide. The level of application depends on the expertise of the companies applying for certification through the GRI: expert (A), introductory $(\mathrm{C})$ or intermediate $(\mathrm{B})$, with an optional "+" $(\mathrm{A}+, \mathrm{B}+$ or $\mathrm{C}+$ ) for audited reports.

General of the United Nations) during the Davos Summit held in 1999, is a global expression of social responsibility. Although the structure of the United Nations was established to address member states directly, new conditions have arisen and globalization has involved companies and non-governmental organizations more directly with the United Nations. 
The guide for the preparation of sustainability reports presents a set of principles that aims to define the contents of the SR and ensure the quality of the information disclosed. The guide also includes performance indicators and other sections.

The overall principles are intended to achieve the transparency that is the basis for all aspects of the development of sustainability reports. The principles, in turn, are organized into two groups. The first group of principles determines issues and indicators about which an organization should report, and the second group ensures the quality and proper presentation of the information disclosed.

Table 2 presents the GRI information principles. For example, the completeness of the report regarding materiality guarantees the minimum impact of economic, environmental and social factors on each stakeholder. However, it is important to preserve the principle of sustainability within the context of an enterprise's competitiveness from a local and a global perspective.

[Table 2 here]

The principles that ensure the quality of information (see Table 3) assure the comparability and accuracy of information to enable stakeholders to make comparisons among enterprises in a specific sector. This kind of information fosters the benchmarking analyses that provide suggestions to organizations seeking to improve their environmental policies.

[Table 3 here]

Regarding report content, the GRI 2006 guide includes three types of information: 1)the plan and profile, 2) the management focus and 3) the performance indicators. The plan and profile establish the overall context for understanding the performance of the organization, including its governance. The GRI covers all aspects of the management approach to provide a context for understanding a company's performance in a particular 
area. The performance indicators enable the comparison of information regarding an organization's economic, environmental and social aspects. The GRI establishes 79 indicators: 9 for economic performance, 30 for environmental performance and 40 for social performance. Social performance is further divided into 14 indicators of employment-related practices: 9 for human rights, 8 for social aspects and 9 for company product liability.

The GRI (2011) presents the following five guidelines for data compilation regarding performance indicators that must be reported: i) reporting on trends, to consider previous, actual, and futures targets (short and medium term), ii) use of protocols, to give basic guidance for interpreting and compiling information, iii) presentation data, to show ratios or normalized data, iv) data aggregation, to determine the appropriate aggregation of data and v) metrics, to use generally accepted international metrics (e.g., kilograms, tons, liters) that are calculated using standard conversion factors.

The first and fifth points offer guidance that could be used in designing indicators to measure efficient performance in different periods of time and to compare these performances with other firms' performances in a specific sector. For example, these techniques can be used to measure the total direct and indirect greenhouse gas emissions by weight, or the initiatives to mitigate environmental impacts of products and services and the extent of impact mitigation. The second point helps the reporter describe basic guidance for interpreting and compiling information examples of initiatives to mitigate the environmental impacts of products and services, strategies, current actions and future plans for managing impacts on biodiversity. Moneva et al. (2006) presented the same idea and explained that the GRI scheme is based on consumption efficiency (materials, energy and water), influence on biodiversity and impact minimization (emissions, wastes and effluents, products and services). 


\section{METHODOLOGY AND RESULTS}

\subsection{Diffusion Models}

The literature relating to the dissemination of different management tools and systems is extensive; this research topic has received significant academic interest in various fields (the synthesis presented in Rogers [1995] is particularly interesting). Specifically, extensive research has been conducted that considers the dissemination of innovative technologies; this research can also be applied, to some extent, to management innovations. For example, Teece (1980) demonstrates that the models of technological innovation are not limited to tangible products. From these studies, it may be generally deduced that the accumulative adoption of innovations over time follows an S-shaped or sigmoid curve; this pattern reflects the fact that few members of a social system adopt an innovation during its initial stages and that the rate at which innovations are adopted increases until the process reaches its saturation point, when the growth rate begins falling again. Stoneman (1995) affirms that this model usually accurately explains diffusion in the field of new technologies.

As reflected in the mathematical literature, the model of the logistic curve was applied for the first time during the nineteenth century by the Belgian mathematician Verhulst in the field of biology to account for the growth of a population. According to this model, the growth rate is at a maximum at the beginning, when there are few individuals in a population and little competition for resources, and the growth rate is reduced to zero once a certain population size is reached. This is the size of saturation that the available resources permit. The model follows the following expression:

$$
N=\frac{N_{0} K}{\left(K-N_{0}\right) e^{-r_{0} t}+N_{0}}
$$

where $\mathrm{N}$ represents the number of individuals in a population, a function of time. $\mathrm{N}_{0}$ represents the number of individuals at the starting point. $\mathrm{K}$ is the maximum level that 
can be reached, i.e., the saturation level. The initial growth rate is determined by $\mathrm{r}_{0}$, and the independent variable, time, is represented by t.

This model has been used successfully by academics to explain the diffusion of the ISO 9001 standard. Franceschini et al. (2004), Marimon et al. (2004, 2006, 2009 and 2010), Casadesus et al. (2008), Llach et al. (2011) and Sampaio et al. (2011) have established that the logistic curve effectively explains the dissemination of the ISO 9000 standard. This model has been applied to other quality management standards as well, such as the "Q" for the tourism sector in Spain (Casadesus et al. 2010). On the basis of the aforementioned work, Marimon et al. (2004, 2006, 2009 and 2010) describe the ways in which the logistic model is also applicable to the diffusion of environmental management systems, particularly the ISO 14000 standard.

In the next subsection, the study discusses the use of the logistic curve pattern in different geographical areas. The study aims to gauge if the model is useful for explaining the diffusion of this particular phenomenon (GRI diffusion). After that, subsection 3.3 will focus the analysis at the activity sector level (microanalysis). The microanalysis will provide evidence regarding the pioneer sectors and will also provide some insight regarding which sectors had important roles in the past and which sectors are now more proactive in the diffusion of GRI adoption.

\subsection{Macroanalysis}

In the present research, the same logistic model is applied to explain the diffusion of the GRI standard. Applying the logistic models previously mentioned to current worldwide GRI data produces the results shown in Figure 1. The data in Table 4 were taken from the GRI (2010) database ${ }^{2}$. The results clearly indicate that the aforementioned model suits

\footnotetext{
${ }^{2}$ This paper focuses on describing and analyzing world statistics of the GRI by countries clustered in continents. However, CRRA (2011) offers statistics related to CSR reporting to those interested in learning about CR reports. On the web page of CorporateRegister.com (http://www.corporateregister.com), the
} 
the current data with a fit of more than 99 percent for $r$ squared. The 1,656 GRI reports filed in 2010 (the last year with available data) represent a worldwide saturation level of 59.5 percent. As previously explained, the theoretical saturation level will never be reached because it is the asymptotic value. To establish a feasible value, this study used 95 percent of the saturation. Previous literature had used the same threshold, and academics have previously accepted this threshold and considered it useful (Franceschini et al. 2004 and 2010, Marimon et al. 2004, 2006, 2009, 2010, Alburquerque et al. 2007, Llach et al. 2011). The model forecasts that this value will be reached in 2015 .

\section{[Table 4 here]}

In Figure 1, the logistic curve has been adjusted to the three geographical areas with the largest figures in 2010 (Table 4). All three regressions fit the data.

Europe has the highest number of certifications. The model forecasts Europe's saturation at 1,639 reports, which means that Europe had reached 50.6 percent of its saturation by 2010. Asia has the second highest number of certifications with 367 , significantly fewer than Europe, and has reached 85.6 percent of its saturation. The contribution of the other geographical areas to the total world figure is relatively small: Africa, North America and Oceania together accounted for 202 reports in 2010.

This same degree of GRI diffusion was found with the ISO 14001 diffusion (Casadesus et al. 2008). Berman et al. (2003) indicate that the GRI followed behind the ISO 14001 standard regarding its influence on social responsibility; thus, it can be assumed that the GRI and the ISO 14001 standards are disseminated following the same pattern.

The model explains previous trends and leads to certain assumptions about the future of the diffusion of these standards. Nevertheless, the diffusion may follow another pattern if

reader can access a database since 1993 to actually view information regarding CSR reporting by continents, countries, economic sectors and others. 
new causes, such as the strengthening of laws or increased numbers of disclosure requests from stakeholders, affect the motivation to fulfill the GRI requirements (Delmas 2002; Delmas and Toffel 2008). Under the current scenario, the model forecasts that in three years, one thousand companies will subscribe to the GRI. Casadesus et al. (2010) explained that the ISO 14001 standards follow three general patterns in the diffusion of these norms: expansionist, mature and retrocession. According to these authors, the normal situation is to pass sequentially through the three states from expansionist to mature to retrocession.

According to this explanation, the GRI is in its expansionist phase; therefore, it is expected that its adoption will increase worldwide, although the degree of adoption depends on other factors such as stakeholder pressure, including that applied by governments (Welford 2004; Prado-Lorenzo et al. 2009; Delmas and Toffel 2008; Tsang et al. 2009), or the drive to improve a country's reputation (Waddock 2008).

\subsection{Microanalysis}

\section{GRI descriptive statistics by world area}

In $2010,1,656$ companies worldwide provided sustainability reports to the GRI, in contrast to the 11 companies that were registered in 1999 . The historical trends for each region, including Africa, Asia, Europe, North America, Latin America and Oceania, are presented in Table 4 according to each continent's number of GRI certifications. Europe and Asia have the first and second highest number of certifications in the GRI. Similar results were reported by Welford (2004), Rowe (2006) and Outtes et al. (2008), who measured GRI adoption over different periods of time.

As previously mentioned, Europe has assigned greater importance to the issue of CSR than other regions have. On average, 50 percent of all CSR reporting occurs in this region. Outtes et al. (2008) note that developed nations implement practical actions that stimulate 
CSR development. For example, the European Commission declared 2005 the year of CSR in countries of the European Union. Other examples come from the United Kingdom, which was the first country to nominate a minister from the Department of Industry and Commerce to oversee sustainability policy. Similarly, France has a mandatory law that states that companies with more than 300 employees must draft social responsibility reports. Other European countries, including Finland, Sweden and Spain, have developed strong relationships with CSR (Levy et al. 2010).

[Figure 1 here]

Though Asia has been growing at a faster rate than other regions, its contribution to SR is still low on a worldwide scale. In 2009, Asia accounted for 20 percent of the enterprises reporting to the GRI. Welford (2004) considers possible explanations for Asia's relatively low CSR activity compared with the CSR activity of Europe and North America. This lack of activity may result from local legislation that dictates the standards of normal working hours, maximum overtime and wage structures. These theories are consistent with Welford's assertion that working long hours is a common practice in Asia.

North America exhibits the lowest growth rate regarding the number of enterprises reporting to the GRI. The US and Canada, countries with a high degree of philanthropic activity (Welford, 2004), pay special attention to child labor, supply chain inspections and local community development. This philosophy may explain why North American society does not need GRI reporting; companies provide this information about their social and sustainability policies through other channels. In 2004, Fortune Magazine found that 90 percent of the top 500 North American corporations had specific CSR initiatives in place (Kotler and Lee 2005). Whereas Gill and Dickinson (2008) suggested 
that North American and European firms have similar levels of reported disclosure activity, Rowe (2006) argues that North America lags significantly behind European countries, as well as India and Japan, in its corporate disclosure reporting. Luna and Fernandez (2008) analyzed the differences in corporate social behavior between North American and European companies and developed a descriptive analysis of their social behavior in both an aggregated and a disaggregated form based on CSR dimensions (customers, employees, community and environment). These authors' results indicate that European companies present a higher frequency of social responsiveness in most of the elements that compose social responsibility than do the North American companies. Particularly, the European companies surpass the North American companies in all elements of responsibility that consider customers and employees. In fact, North American companies surpass European companies in only one element of environmental responsibility: information on accidents, spills and other incidents. However, the North American companies score higher than the European companies in 5 of the 12 elements pertaining to community responsibility. Similar differences in European and US-based companies were found by Konrad et al. (2006).

Oceania and Africa have much less historical importance in SR, with an average of only 4 percent of companies reporting. Truscott et al. (2009) argued that CSR is becoming increasingly popular in Australia, which is reflected in CSR-related studies conducted by commercial firms and professional bodies. In addition to the development of the Australian CSR standard, a variety of indices have been developed to evaluate company performance with respect to social and environmental issues.

Within the context of developing countries, CSR research tends to be more dominant in Asia than in either Africa or Latin America. In addition, Visser (2006) noted that the literature has been fragmented and limited with an overwhelmingly skewed focus on 
South Africa. Idemudia (2011) mentioned that although a critical CSR research agenda exists with respect to the African context, the broad categories are based largely on the significant contribution these categories make to the advancement of CSR theory and practices in developing countries, particularly in Africa (Levy et al. 2010).

Latin America has made a relatively small contribution even though its growth rate is higher than the world average. Although we find when comparing 2009 figures that Latin and North America place the same level of importance on CSR, as Jamali (2007) notes, CSR has not found similar interest in developing countries because their civil societies are not well organized and the government does not strongly promote CSR. This situation mainly arises from the fact that institutions, standards and systems, which are the foundation of CSR in Europe and the US, are comparatively weak in developing nations (Kemp 2001).

These results are similar to those found by the ACCA (2004), which determined that North America and Western Europe are the most active reporting regions. In contrast, non-financial reporting of any kind remains relatively unknown in the Caribbean and most of Latin America. Asia, too, demonstrates a low incidence of corporate reporting outside of Australia and Japan, but reporting is expected to increase in China in the near future (Waddock 2008). Finally, across Africa and the Middle East, only South Africa has demonstrated significant reporting activity. Therefore, following Outtes et al. (2008), it can be concluded that CSR adoption is strongly influenced by the country of origin.

\section{GRI descriptive statistics by sector}

The GRI has been adopted by 38 different sectors that range from agriculture to financial services. Figure 2 displays a positive trend in the monitoring of the GRI in each of the top seven sectors (together, these sectors account for 44.8 percent of the GRI reports in 2010). 
Financial services represent the leading sector in recent years. Ogrizek (2002) mentions that financial services firms are taking CSR more seriously than they did in the past because of the influence of the US, where important legal factors and activism drive financial firms. In the US, managing CSR issues thus becomes more important than philosophy. European banks usually begin with a corporate philosophy and try to apply their principles to local realities and individuals. These banks focus mainly on the environment and on a sustainable development policy. Moreover, current markets consider the financial services sector partly responsible for the current financial crises. The energy sector (see the "Energy" and "Energy Utilities" categories in Figure 2), which includes oil enterprises, has been experiencing significant growth. Thus, it is essential that the negative impacts of this sector on the environment be noted. Sectors such as financial services and food and beverage products have maintained growth similar to the growth levels of the energy sector.

[Figure 2 here]

Frynas (2010) found that the oil and gas sector (energy) has been among the leading industry sectors in championing CSR. The ACCA 2004 study identified chemical, electric, oil-gas and mining companies as the most proactive in publishing social reports and showing environmental sensitivity.

Outtes et al. (2008) also found a link between industry sector and CSR, finding that, in emerging countries, banking, oil and telecommunications are pioneering CSR reporting. In addition, Azim et al. (2009) present an empirical investigation into the corporate social reporting practices of listed companies from Bangladesh, revealing that companies in the banking sector have the highest rank in terms of corporate social reporting. The results are presented in Figure 2. 
Following the methodology proposed by Marimon et al. (2006 and 2011), this study examines the evolution of instability and the concentration of the GRI rankings to compare the diffusion of a standard among different activity sectors. A complementary analysis was performed using commonly used indicators to determine the degree of competition that companies experience in a given market, e.g., indicators of the degree of instability and of concentration in the relevant sectors. This study uses these commonly used market research indices to determine if the sectors that were the leaders (and hence tractors or pioneer sectors) at the beginning of the decade are still the tractors now (instability index) and, moreover, if the degree of importance of these leader sectors has been changing (concentration index).

\section{Instability index}

The level of stability indicates the relative position of each company, over time, in the market, whereas the degree of concentration refers to the market share enjoyed by the leading companies. Both concepts are applied to the presence of companies from each sector of economic activity in relation to the total number of certifications. Thus, the same tools used to describe certifications among companies are applied to certifications among sectors. Figure 3 illustrates the evolution of the GRI certification rankings by sector of activity, showing the seven sectors that occupied the top positions in 2010. Note that several positions are empty, including the second position in 2010 , the third position in 2009, the fourth position in 2008 and others. These omissions result because we have not graphed a sector labeled "Others."

[Figure 3 here]

As indicated in Figure 3, the five highest-ranked sectors have maintained their positions in recent years. Figure 3 confirms what is explicitly shown in Figure 2: the relative 
positions in the rankings are becoming more stable. Some indices, such as the McR index, measure instability (Llach et al. 2011). The most common instability index, defined below, has been used throughout this chronological series:

$$
I=\frac{1}{2} \sum_{i=1}^{n}\left|s_{i 2}-S_{i 1}\right|
$$

where $s_{i 1}$ and $s_{i 2}$ are the quotas of sector i during periods 1 and 2. The index ranges from zero (minimum instability) to one (maximum instability). The value $I=0$ relates to a situation in which all the sectors keep their share; the value $I=1$ corresponds to a situation in which all the sectors competing in the initial period are removed from the market in the second period. Other indices also use a ranking to measure instability.

[Figure 4 here]

The trend is evolving toward lower values of instability (Figure 4). The GRI standard is maturing, and, over time, the positions in the rankings are becoming more stable, confirming what is shown in Figure 3: the positions of the most important sectors stabilize over time.

\section{Concentration index}

For the purpose of studying the degree of concentration, this study used the Herfindahl index. Greer (1992) and Cabral (1997) are among those who maintain that this index constitutes a useful means of analyzing concentration because it was originally designed to measure the concentration of market share held by particular suppliers in a market. The index is defined as follows:

$$
H=\sum_{i=1}^{n} s_{i}^{2}
$$


where $s_{i}$ is the quota of sector $\mathrm{i}$, and $\mathrm{n}$ is the number of sectors. The value of $H$ varies between $1 / \mathrm{n}$ (minimum concentration) and 1 (maximum concentration). In our case, the minimum level is $0.026(1 / 38)$. While other indices can evaluate the concentration effect, this index has the highest degree of consistency (Jacquemin, 1987).

Figure 5 shows that this concentration index has an evolution similar to that observed in the case of the instability index. Over time, the values begin to indicate a low level of concentration. Although the figures for the different sectors have tended to level out, a significant difference still exists, for instance, between the financial services sector, with a rating of 13.94 percent for 2010, and the toys sector, with a share of 0.11 percent.

\section{[Figure 5 here]}

Figure 5 shows that both the instability and the concentration indices exhibit a trend toward the stabilization of the positions of each sector in the GRI reporting rankings on a worldwide basis. In recent years, the relative positions have been maintained, and there has been an ever-increasing leveling out in the number of certifications per sector.

\subsection{Discussion of the Results}

Lozano and Huising (2011) declared that the number of companies that have adopted GRI reporting is still very low. The GRI database (2010) indicates that only 1,656 companies use this standard to disclose non-financial information, which, considering the number of companies worldwide, is an extremely small portion.

Regarding diffusion by geographical area, the findings confirm previous research showing that Europe has been the leader in GRI adoption since its foundation. Prior research has identified governments as critical stakeholders in the adoption of the GRI (Delmas and Toffel 2008; Prado-Lorenzo et al. 2009). In fact, it is the legislators who have promoted social reporting in several European countries, including Austria, 
Belgium, Denmark, the Netherlands, Norway and Sweden (Tsang et al. 2009). Prior research also suggests that in response to regulation, more European companies will adopt the GRI standard for SR in the near future.

Surprisingly, North American companies have not adopted the GRI as quickly as expected, although SR has been adopted among large international companies (Koerber 2010). According to Levy et al. (2010, 89), in the US, "the uptake and diffusion of GRI to new organizations is stagnating[...] primarily due to a failure to deliver value to various stakeholders." Regarding the GRI adoption level in North America, some researchers find that investors are not convinced that SR is valuable in the pricing of financial assets. Another drawback that explains the poor diffusion of the GRI is that companies do not believe in the payoffs to be gained from social performance. That is, establishing policies of corporate governance to accommodate the needs of civil society is considered to be very expensive by company executives. Therefore, both GRI data and prior research suggest that GRI adoption will not expand at the same rate in North America as it has on other continents.

Although legislation is an important driver for adopting the GRI standard, it is not the only one. Many studies (e.g., Delmas 2002; Konrad et al. 2006; Gilbert and Rache 2007; Delmas and Toffel 2008; Waddock 2008; Perez-Batres et al. 2010) suggest that other drivers - such as international commerce, or the desire to achieve market trust, attract or maintain investors or improve country image — are relevant in the decision to adopt the GRI. Therefore because there is a general consensus regarding the GRI as a standardized instrument to enable stakeholders' communication (Willis 2003), the business strategy and the identification of main stakeholders for the company could also act as drivers to GRI adoption. 
These reasons could explain why Asia has the second highest rate of GRI adoption, led by China. This country has been accused of ecological devastation and major abuses of global supply chains and human rights, and, therefore, it is focused on improving its CSR practices and sustainability reputation (Waddock 2008). Pursuant to these goals, China, as predicted by this study, is likely to increase its GRI adoption. Other Asian countries share a similar situation (Saleh, 2009).

In the case of Latin America, the economic growth experienced by some countries suggests a greater influence of stakeholders over the companies (Delmas and Toffel, 2008). Perez-Batres et al. (2010) also empathize the growing normative and mimetic pressure due to European and US influence. Therefore, researchers expect an increased emphasis on the adoption of CSR and GRI (Alonso-Almeida et al. 2011) in the short term to the extent that it serves as a basis for stakeholder debate.

Waddock (2008) asserted that the model of SR used in developed countries is not appropriate and will not work for all countries. Alonso-Almeida et al. (2011) concluded in their study on CSR in Mexico that CSR should be developed according to the specific environmental and social needs of the particular territory.

Accordingly, the adoption of CSR practices could follow a different pattern in developed countries than it is in developing countries. Different patterns may result because the cultural, legal, political, economic and social dimensions and the adoption drivers are different in developing than in developed countries. Moreover, the reasons to pursue the GRI seem different in developed countries than they are in developing countries. Thus, because companies in developed countries seek to gain in reputation, they emphasize minorities or gender mainstreaming in internal activity while also emphasizing strategic social actions in the companies' external dimensions (Konrad et al., 2006). On the contrary, developing countries wish to achieve visibility for international investors. To 
achieve this goal, they focus on compliance with current, basic international requirements concerning products and some social items, such as human rights, in their human management practices.

Thus, while governments in developed countries have been the main promoters of CSR practices, governments in developing countries seem reluctant to recommend and legislate environmental care or labor force conditions or to confront corruption. Developing countries are making intense efforts to attract new foreign direct investments. To attract these investments, companies likely need to be more transparent regarding aspects that concern investors (Gilbert and Rache 2007). As Saleh (2009) stated, enhancing CSR practices "may help firm reach pools of capital it might not otherwise be able to tap into".

Given that the GRI has been created to satisfy the specific needs of relevant stakeholders (Koeber 2010), companies that have adopted the GRI in developing countries could send a signal to the main stakeholders and markets about their contempt for corruption, the abuse of labor force or environmental destruction. In addition, Asian companies could be required to prove the elimination of some undesirable practices when they export to European or US countries. In this case, GRI adoption could act as a proof to open the door to foreign markets.

Finally, though some efforts toward GRI adoption are being made in some African countries (Levy et al. 2010), a high rate of adoption cannot be expected because the development of management standards is in its nascent period (ISO, 2010b). Mitchell and Hill (2009) stated that the GRI reporting in South Africa is endorsed by the King Report for Corporate Governance and the Johannesburg Stock Exchange for listed companies; therefore, GRI reporting applies only to a limited number of companies. The same 
situation has been found in Bangladesh (Naemen and Walford 2009, Sobhani et al. 2011) and Pakistan (Naemen and Walford 2009).

It can be concluded that although the different behaviors in GRI adoption suggest that GRI adoption will continue to grow, each characteristic and environment should be studied separately and in greater depth.

Regarding the adoption of the GRI by industries, this study suggests that the sectors that are the most harmful to the environment are the earlier and more comprehensive SR adopters (Tsang et al. 2009). Accordingly, this study corroborates previous research in its findings that energy (and energy utilities), chemistry and mining are the main sectors to disclose information using the GRI. Similarly, Lagodimos et al. (2007) found that manufacturing industries that perform hazardous activities or produce harmful products have a higher diffusion of environmental standards than commerce and service sectors do. Casadesus et al. (2008) reported similar results in their study of ISO 14001 diffusion in Spain.

Thus, although there may be a saturation occurring among some pioneer sectors, others may be in the earliest stages of adoption. Therefore, GRI adoption may well increase in some sectors and decrease or remain stagnant in others. Moreover, given the distrust of the market in certain sectors, such as financial services, it is expected that the most visible sectors will continue to adopt SR to gain the trust of and develop closer relations with their main stakeholders (Callan and Thomas 2009).

At this time, it is difficult to speculate about the behavior of each individual sector. These speculations would require a comparative study by sector of each activity. Such a comparative study is proposed as a future line of research.

\section{CONCLUSIONS}


The findings of this study provide a number of conclusions and trends that deserve more detailed explanation. First, this study has found that enterprises have increased their participation in sustainable reporting standards, i.e., in the GRI (Arevalo and Fallon 2008), but the accumulated percentage is small given the enormous number of companies worldwide. Moreover, Koerber (2010) finds that 80 percent of the reports on environmental issues indicate that companies use their own guides for social responsibility rather than using a standard such as the GRI. This decision may be explained in part by ignorance on the part of the companies, particularly small and medium-sized firms, given that the disclosure of non-financial results is both expensive and somewhat complex (Levy et al. 2010). Furthermore, small and medium-sized companies have less visibility and fewer incentives than large companies to adopt the GRI. Despite these disadvantages, the GRI is making a significant effort to reach the SMEs in Brazil, China, India, Indonesia and Mexico (Levy et al. 2010). Consequently, researchers expect that the number of GRI adopters will increase markedly in these areas. Second, the recent trend of GRI adoption suggests that more firms are adopting the initiative. Ceteris paribus, the adoption follows the same diffusion pattern in different geographical areas. According to Luna and Fernandez (2008), European companies surpass the rest of the world's companies because European countries place greater emphasis on customers and employees as relevant stakeholders. Thus, it is concluded that customers and employees recognize the social responsibility and relevant actions of those companies that have increased consumer demand or higher worker productivity (Callan and Thomas 2009).

Furthermore, Ortas and Moneva (2011) find that changes in the number of GRI reports present special features depending on the region considered. These authors also report that companies located in regions such as Europe and Asia have always been leaders in 
the field regarding the number of GRI reports disclosed. However, other areas, such as Latin America, show recent significant growth.

Third, the adoption of the GRI has occurred earlier and been more rapid in those sectors where the environment and society are at increased risk and the visibility in the capital market is higher (Callan and Thomas 2009). This pattern is evident with other international standards as well, such as ISO 14000 (Casadesus et al. 2008). Accordingly, saturation in these sectors is expected in the near future.

Fourth, with respect to trends in the adoption of the GRI, adoption rates will slightly increase in the next three years despite the high costs associated with the collection, verification and design of reports (Koerber 2010; Levy et al. 2010). As a result of several key factors, the future will see major growth in contrast to what has been experienced in the past. The first factor affecting the growth of the GRI is the standardization of SR in capital markets. According to Willis (2003), the GRI is a tool that allows companies to communicate to stakeholders about their actions and performances beyond their financial indicators. Thus, investors interested in long-term, sustainable companies count on the GRI as a mechanism for the standardization of information. Therefore, financial markets could require more transparent reporting mechanisms, which will promote the GRI or other social mechanisms for reporting growth.

The second key factor affecting GRI growth is the need to compare the performance of specific sectors in the international market. Waddock (2008) stated that an increasingly popular way of pressuring companies to be more responsible is through the publication of ratings and rankings that compare companies' social performance. According to Beţianu (2010), it is important for social performance that indicators be related to financial reporting. 
Research further suggests that new methodologies should help link economic, environmental and financial data. Accordingly, the GRI guidelines created for some sectors, such as energy, oil and gas, and food processing, allow for closer comparison among companies in these sectors. These guidelines will provide these sectors with more specific indicators that will, in turn, simplify the GRI application.

The third key factor that will trigger the adoption of the GRI is the role of compliance as a differentiation strategy from competition. Social responsibility standards can be directed toward the company as a factor influencing competition (Khanna 2001). As Porter and Kramer (2006) indicated, when the standards of social responsibility are aligned, company strategy can be used to identify a competitive advantage.

Finally, the fourth key factor concerns regulators who seek to strengthen administrative values. Administrators have some degree of discretion in the way they interact with their stakeholders and distribute resources (Weaver et al. 1999). Although not all companies are yet engaged at a high level, many companies place significantly more emphasis on responsible practices than they have in the past (Waddock 2008). As Levy et al. (2010) stated, the "GRI is most important as a tool for managing corporate sustainability efforts, assessing and protecting corporate reputation, and enhancing brand values." Therefore, it can be concluded that these trends support the predicted increase in GRI adoption.

Moreover, it is worthwhile to outline the future challenges that may inhibit the adoption of the GRI guidelines. Based on the findings of this research, these challenges would primarily concern two important issues. First, the GRI standards must be more flexible to accommodate the differing perspectives of countries, sectors and institutions. Brown et al. (2009b) argued that the challenge the GRI faces is to create a common language that can be used by others to form judgments about the reported performance and that over time can lead to the emergence of a societal consensus about what constitutes acceptable 
norms of sustainability behavior. The participation and support of companies from different sectors and geographic regions is therefore essential. However, Preuss and Barkemeyer (2011) found that sustainability reporting according to the GRI framework is predominantly taken up by large firms. Therefore, strong efforts should be made to include more small companies and companies from developing countries. In line with this reasoning, the GRI could play a crucial role with the support and cooperation of all institutes that promote SR worldwide.

The second challenge the GRI faces concerns its evolution. Brown et al. (2009b) noted that the GRI built-in process for producing successive generations of the guidelines, sector supplements and country specific annexes would assure future, broadly based participation and support. GRI (2012) argues that the fourth generation of the GRI's Guidelines "G4" is planned for 2013. The new GRI Guidelines face the challenge of harmonizing with other relevant international reporting guidance, considerably improving guidance concerning the definition of "materiality" and re-designing the format to offer major comparability between sectors and countries.

Finally, this study has determined some lines of future research. Many previous studies have considered the importance of other standards and have highlighted the diffusion of the adoption of an integrated management system (Zeng et al. 2005; Bernardo et al. 2009; Karapetrovic y Casadesus 2009; Sakr et al. 2010; Bernardo et al. 2011). Considering this research, it would be interesting to study the integration of ISO 26000 and SR standards into a company's integrated management system, given that the GRI and ISO 14001, OHSAS 18001 and ISO 26000 could be compatible for integration (Reynolds and Yuthas 2008).

However, given the exploratory nature of this study, it is strongly recommended that future research establish stronger evidence for the role of the GRI and other SR standards. 
For future research, a study that explores whether GRI adoption by sector differs from GRI adoption by country would be valuable. Furthermore, confirmation of the future evolution of GRI adoption along with a detailed analysis of the GRI as an institutional perspective would be of interest. Another possible line of future research might include an in-depth study of business cases with the purpose of analyzing the motives for and impacts of the adoption of social standards. 


\section{Acknowledgments}

This article was written as part of a research project titled "Customer satisfaction improvement in Spanish organizations through standardization" (ECO2009-12754-CO2-

01), which was financed by the Ministry of Science and Innovation as part of its aid program for R\&D projects. Part of this study was also sponsored by the Universidad Autónoma de Nuevo León (PAICYT, GCS043-10). 


\section{References}

Albuquerque, P., Bronnenberg, B. And Corbett, C. 2007. “A Spatiotemporal Analysis of the Global Diffusion of ISO 9000 and ISO 14000 Certification”. Management Science. 53(3) 451-468.

Alonso-Almeida, M.M., M.P. Rodríguez García, K.A. Cortez, and J.L. Abreu-Quintero. 2011. "La responsabilidad social corporativa y el desempeño financiero. una aplicación empírica en las empresas mexicanas cotizadas". Contaduría y Administración..57 (1), 53-77.

Asif M., C.Searcy, A. Zutshi, O.Fisscher . 2011. “An integrated management systems approach to corporate social responsibility". Journal of Cleaner Production, In Press, Corrected Proof, Available online 2 November 2011.

Association of the Chartered Certified Accountants (ACCA). 2004. Towards transparency: progress on global sustainability reporting 2004, ACCA. London: Business for Social Responsibility.

Azim, M.I., S. Ahmed, and M. Islam. 2009. “Corporate Social Reporting Practice: Evidence from Listed Companies in Bangladesh." Journal of Asia-Pacific Business 10 (2): 130-145.

Arevalo, J.A. and F.T. Fallon. 2008. “Assessing Corporate Responsibility as a Contribution to Global Governance: The Case of the UN Global Compact." Corporate Governance 8 (4): 456-470.

Berman, J.E., T. Webb, D.J Fraser, P.J. Harvey, J. Barsky, and A. Haider. 2003. Race to the top: Attracting and enabling global sustainable business, Business Survey Report. Washington, DC: World Bank Group. 
Bernardo, M., Casadesus; M., Karapetrovic, S., Heras, I. 2011. "Do integration difficulties influence management system integration levels?" Journal of Cleaner Production 21 (1): 23-33

Bernardo, M., Casadesus, M., Karapetrovic, S., Heras, I., 2009. "How integrated are environmental, quality and other standardized management systems? An empirical study". Journal of Cleaner Production 17 (8): 742-750.

Beţianu, L. 2010. "Indicators of The Global Reporting Initiative Regarding Sustainable Development." Annales Universitatis Apulensis Series Oeconomica 12 (1): 15-24.

Brown, H.S., M. de Jong, , D.L. Levy. 2009a. "Building institutions based on information disclosure: lessons from GRI's sustainability reporting”. Journal of Cleaner Production, $17(6), 571-580$.

Brown H.S., M. de Jong, T. Lessidrenska 2009b. "The rise of the Global Reporting Initiative: a case of institutional entrepreneurship". Environmental Politics, 18 (2): 182200.

Cabral, L. 1997. Economía industrial, 1st ed. Madrid, Spain: McGraw-Hill.

Callan, S. J. and J.M. Thomas. 2009. "Corporate Financial Performance and Corporate Social Performance: An Update and Reinvestigation." Corporate Social Responsibility and Environmental Management 16: 61-78.

Casadesus, M., Marimon, F. and Heras, I. 2008. "Countries behavior regarding to the difussion of ISO 14000 standards." Journal of Cleaner Production 16: 1741-54.

Casadesus, M., Marimon, F. and Alonso, M. 2010. "The Future of Standardised Quality Management in Tourism: Evidence from the Spanish Tourist Sector" Service Industries Journal 30 (14): 2457-74.

Clarkson, P. M., M. B. Overell, and L. Chapple. 2011. "Environmental Reporting and its Relation to Corporate Environmental Performance”. Abacus, 47: 27-60. 
Clarkson, P., Y. Li, G. Richardson, and F. Vasvari. 2008. "Revisiting the Relation Between Environmental Performance and Environmental Disclosure: An Empirical Analysis", Accounting. Organizations and Society, 33 (4/5): 303-327

Ciliberti F., J. Haan, G. Groot and P. Pontrandolfo 2011. "CSR codes and the principalagent problem in supply chains: four case studies". Journal of Cleaner Production, 19: 885-894

Cornelius, N., J. Wallace, and R. Tassabehji. 2007. “An Analysis of Corporate Social Responsibility, Corporate Identity and Ethics Teaching in Business Schools.” Journal of Business Ethics 76: 117-35.

CRRA (2011). CR Reporting Award'11, London: Corporate Register Reporting Award.

Delmas, M. A. and M. J. Montes-Sancho. 2010. “An Institutional Perspective on the Diffusion of International Management System Standards: The Case of the Environmental Management Standard ISO 14001.” Business Ethics Quarterly, Forthcoming. Available at SSRN: http://ssrn.com/abstract=1684923

Delmas, M.A., and M.W. Toffel. 2008. “Organizational responses to environmental demands: opening the black box.” Strategic Management Journal 29 (10): 1027-55.

Delmas, M.A. 2002. "The diffusion of environmental management standards in Europe and in the United States: an institutional perspective.” Policy Sciences 35: 91-119.

Franceschini, F., M. Galetto, and G. Gianni. 2004. "A new forecasting model for the diffusion of ISO 9000 standard certifications in European countries." International Journal of Quality \& Reliability Management. 21(1): 32-50.

Franceschini, F., Galetto, M., Maisano, D. and Mastrogiacomo, L., 2010, “Clustering of European countries based on ISO 9000 certification diffusion”. International Journal of Quality \& Reliability Management 27 (5): 558-575. 
Freedman, M., and C. Wasley 1990. “The Association Between Environmental Performance and Environmental Disclosure in Annual Reports and 10ks " Advances in Public Interest Accounting 3: 183 -193

Frynas, J.G. 2010. “Corporate Social Responsibility and Societal Governance: Lessons from Transparency in the Oil and Gas Sector." Journal of Business Ethics 93: 16379.

Gilbert, D. U., and Rasche, A. 2007. "Discourse ethics and social accountability: the ethics of SA 8000". Business Ethics Quarterly 17 (2): 187-216.

Gill D. L., and Dickinson S.J. 2008. “Communicating sustainability. A web content analysis of North American, Asian and European firms." Journal of Communication Management 12 (3): 243-62.

Greer, D.F. 1992. Industrial organization and public policy, 3rd ed. New York: MacMillan Publishing Company.

GRI 2006. Sustainability Reporting Guidelines, Version 3, Amsterdam: Global Reporting Initiative.

GRI. 2010. "Report List.” Accessed April 2011. http://www.globalreporting.org/ReportServices/.

GRI 2011. Sustainability Reporting Guidelines, Version 3.1., Amsterdam: Global Reporting Initiative.

GRI 2012. G4 Development, First PCP Summary Report, Amsterdam: Global Reporting Initiative.

Idemudia, U. 2011. “Corporate social responsibility and developing countries: moving the critical CSR research agenda in Africa forward." Progress in Development Studies 11 (1): 1-18. 
Ingram, R., and K. Frazier 1980. "Environmental Performance and Corporate Disclosure". Journal of Accounting Research. 18 (2): 614-622

ILO. 2006. Tripartite declaration of principles concerning multinational enterprises and social policy, 4th Ed, Geneva: International Labour Organization

ISO. 2007. ISO 14000. Environmental management. Geneva: International Organizaton for Standardization

ISO. 2010a. ISO 26000 Guidance on social responsibility, Geneva: International Organizaton for Standardization.

ISO. 2010b. "The ISO survey of ISO 9000 and ISO 14000 Certifications: 18th cycle, ISO, Geneva.” Accessed August 9, 2011. http://www.iso.ch/iso/en/iso900014000/iso9000/survey18thcycle.pdf

Jacquemin, A. 1987. The new industrial organization: Market forces and strategic behavior, 1st ed. MA: The MIT Press.

Jamali, D. 2007. “The Case for Strategic Corporate Social Responsibility in Developing Countries.” Business and Society Review 112 (1): 1-27.

Karapetrovic, S., Casadesús, M., 2009. Implementing environmental with other standardised management systems: Scope, sequence, time and integration. Journal of Cleaner Production. 17: 533-540.

Kemp, M. 2001. “Corporate Social Responsibility in Indonesia: Quixotic Dream or Confident expectation?” Program Paper No. 6. Geneva, Switzerland: United Nations Research Institute for Social Development.

Khanna, M. 2001. "Non-Mandatory Approaches to Environmental Protection.” Journal of Economic Surveys 15 (3): 291-324.

Koerber, C.P. 2010. “Corporate Responsibility Standards: Current Implications and Future Possibilities for Peace through Commerce." Journal of Business Ethics 89: $461-80$. 
Konrad A., Steurer, R., Langer, M. E., Martinuzzi, A. 2006. "Empirical Findings on Business-Society Relations in Europe". Journal of Business Ethics 63: 89-105. Kotler, P., and N. Lee. 2005. Corporate Social Responsibility: Doing the Most Good for Your Company and Your Cause. Hoboken, NJ: John Wiley \& Sons Inc.

Krajnc, D., and P. Glavi. 2005. “A model for integrated assessment of sustainable development. Resources, Conservation and Recycling 43: 189-208.

Lagodimos, A., P. Chountalas, and K. Chatzi. 2007. "The state of ISO 14001 certification in Greece.” Journal of Cleaner Production 15 (18): 1743-54.

Levy D.L., H. Szejnwald Brown, and M. de Jong. 2010. “The Contested Politics of Corporate Governance the Case of the Global Reporting Initiative.” Business \& Society 49 (1): 88-115.

Ligteringen, E., and S. Zadek. 2004. "The Future of Corporate Responsibility Standards. Accounting Forum 4: 6-17.

Llach, J., Marimon, F. and Bernardo, M. 2011. "ISO 9001 diffusion analysis according to activity sectors.” Industrial Management \& Data Systems 111 (2): 298-316.

Lozano, R., and D. Huisingh. 2011. "Inter-linking issues and dimensions in sustainability reporting." Journal of Cleaner Production 19: 99-107.

Luna L.S., and J.L. Fernández. 2008. "Corporate Social Responsibility of the Most Highly Reputed European and North American Firms." Journal of Business Ethics 82: $379-90$

Manetti, G. 2011. "The Quality of Stakeholder Engagement in Sustainability Reporting: Empirical Evidence and Critical Points." Corporate Social Responsibility and Environmental Management 18: 110-22. 
Marimon, F., Casadesus, M. and Heras, I. (2004), “A Dynamic Model for the Diffusion of ISO 9000 and ISO 14000 Standards”, Proceedings of the International Conference on Modelling \& Simulation, Valladolid, Spain.

Marimon, F., M. Casadesús, and I. Heras. 2006. "ISO 9000 and ISO 14000 standards: An international diffusion model.” International Journal of Operations and Production Management 26 (2): 141-65.

Marimon, F., M. Casadesús, and I. Heras. 2009. "ISO 9000 and ISO 14000 standards: a projection model for the decline phase." Total Quality Management \& Business Excellence 20 (1): 1-21.

Marimon, F., M. Casadesús, and I. Heras. 2010. "Certification Intensity Level of the leading nations in ISO 9000 and ISO 14000 standards." International Journal of Quality \& Reliability Management 27 (9): 1002-20.

Marimon, F., J. Llach, and M. Bernardo. 2011. "Comparative analysis of diffusion of the iso 14001 standard by sector of activity." Journal of Cleaner Production 19 (15): $1734-44$.

Melé, D., P. Debeljuh, and M.C. Arruda. 2006. “Corporate Ethical Policies in Large Corporations in Argentina, Brazil and Spain.” Journal of Business Ethics 63: 21-38.

Mitchell C. G. and Hill T. 2009. "Corporate Social and Environmental Reporting and the Impact of Internal Environmental Policy in South Africa." Corporate Social Responsibility and Environmental Management 16: 48-60.

Moneva J., P. Archel, C. Correa 2006. "GRI and the camouflaging of corporate unsustainability”. Accounting Forum, 30: 121-137

Naeem M. A. and Welford R. 2009. "A Comparative Study of Corporate Social Responsibility in Bangladesh and Pakistan." Corporate Social Responsibility and Environmental Management 16: 108-122 
O'Connor Martin and Spangenberg Joachim 2008. "A methodology for CSR reporting: assuring a representative diversity of indicators across stakeholders, scales, sites and performance issues." Journal of Cleaner Production 16: 1399-1415

Ogrizek, M. 2002. "The effect of corporate social responsibility on the branding of financial services." Journal of Financial Services Marketing 6 (3): 215-28.

Ortas, E., and J.M. Moneva. 2011. “Origins and development of sustainability reporting: Analysis of the Latin American context." Journal of Globalization, competitiveness \& Governability 5(2): 16-37.

Outtes Wanderley, L., L. Soares, R. Lucian, F. Farache, and J. de Sousa Filho Milton. 2008. "CSR Information Disclosure on the Web: A Context-Based Approach Analysing the Influence of Country of Origin and Industry Sector." Journal of Business Ethics 82: 369-78.

Perez-Batres L.A., V.V. Miller, and J.P. Pisan. 2010. "CSR, Sustainability and the Meaning of Global Reporting for Latin American Corporations.” Journal of Business Ethics 91: 193-209.

Prado-Lorenzo, J.M., I. Gallego-Alvarez, and I.M. Garcia-Sanchez. 2009. "Stakeholder Engagement and Corporate Social Responsibility Reporting: the Ownership Structure Effect." Corporate Social Responsibility and Environmental Management 16: 94-107.

Preuss L. and R. Barkemeyer 2011. "CSR priorities of emerging economy firms: is Russia a different shape of BRIC?". Corporate Governance. 11 (4), 371-385

Porter, M.E., and M.R. Kramer. 2006. "Strategy \& Society: The Link between Competitive Advantage and Corporate Social Responsibility." Harvard Business Review 84 (12): 78-92. 
Rasche, A. 2009. “Toward a Model to Compare and Analyze Accountability Standards - The Case of the UN Global Compact." Corporate Social Responsibility and Environmental Management 16: 192-205.

Reynolds M.A. and Yuthas, K. 2008. Moral Discourse and Corporate Social Responsibility Reporting. Journal of Business Ethics 78:47-64

Roca L.C.and C. Searcy 2012. "An analysis of indicators disclosed in corporate sustainability reports". Journal of Cleaner Production, 20, 103-108

Rogers, E.M. 1995. Diffusion of Innovations. NY: Free Press.

Rowe, M. 2006. "Reputation relationships and risk: a CSR primer for ethics officers." Business and Society Review 111 (4): 441-55.

SAI. 2008. Social accountability 8000. New York: Social Accountability International. Saleh M. 2009. "Corporate Social Responsibility Disclosure in an Emerging Market: A Longitudinal Analysis Approach." International Business Research 2 (1): 131-141. Sampaio, P., P. Saraiva, and A. Rodriguez. 2011 "ISO 9001 certification forecasting models." International Journal of Quality \& Reliability Management 28 (1): 5-26.

Sakr, D.A., Sherif, A., El-Haggar, S.M., 2010. "Environmental management systems awareness: an investigation of top 50 contractors in Egypt." Journal of Cleaner Production 18: 210-218.

Schadewitz, H., and M. Niskala. 2010. “Communication via Responsibility Reporting and its Effect on Firm Value in Finland." Corporate Social Responsibility and Environmental Management 17: 96-106.

Skouloudis A., K. Evangelinos, and F. Kourmousis. 2009. "Development of an Evaluation Methodology for Triple Bottom Line Reports Using International Standards on Reporting.” Environmental Management 44: 298-311. 
Sobhani F. A., Zainuddin, Y., Amran A. and Baten Md. A. 2011. "Corporate sustainability disclosure practices of selected banks: A trend analysis approach." African Journal of Business Management 5(7): 2794-2804

Stoneman, P. 1995. Handbook of the Economics of Innovation and Technological Change. Oxford, UK: Blackwell Handbooks in Economics.

Teece, D. 1980. "The diffusion of an administrative innovation." Management Science 26 (5): 464-70.

Truscott, R.A., J.L. Barrtlett, and S. Tywoniak. 2009. "The reputation of Corporate Social responsibility industry in Australia." Australasian Marketing Journal 17 (2): 84-91.

Tsang, S., R. Welford, and M. Brown. 2009. "Reporting on Community Investment." Corporate Social Responsibility and Environmental Management 16: 123-36.

Visser, W. 2006. "Research on corporate citizenship in Africa: A ten year review (1995-2005)." In Corporate Citizenship in Africa: Lessons from the Past: Paths to the Future, edited by W. Visser, M. McIntosh, and C. Middleton, 18-28. Greenleaf Publishing.

Waddock, S. 2008. "Building a New Institutional Infrastructure for Corporate Responsibility." Academy of Management Perspectives (August): 87-108.

Weaver, G.R., L.K. Trevino, and P.L. Cochran. 1999. “Integrated and Decoupled Corporate Social Performance: Management Commitments, External Pressures, and Corporate Ethics Practices.” Academy of Management Journal 42 (5): 539-52.

Welford, R. 2004. “Corporate Social Responsibility in Europe, North America and Asia." The Journal of Corporate Citizenship 17: 33-52. 
Willis, A.C. 2003. “The role of the global reporting initiative's sustainability reporting guidelines in the social sustainability reporting guidelines in the social screening investments." Journal of Business Ethics 43 (3): 233-7.

Zeng, S.X., Tam, C.M., Tam, V.W.Y., Deng, Z.M., 2005. "Towards implementation of ISO 14001 environmental management systems in selected industries in China." Journal of Cleaner Production 13: 645-656. 
Tables

Table 1. Tools for Assessing and Reporting Sustainability

\begin{tabular}{|c|c|c|c|c|}
\hline & Institution & Brief Description & Objective & Focus Areas \\
\hline \multirow{3}{*}{$\begin{array}{c}\text { Normative } \\
\text { frameworks: Provide } \\
\text { guidance on } \\
\text { acceptable } \\
\text { performance goals }\end{array}$} & $\begin{array}{c}\text { UN Global Compact } \\
\text { Principles } \\
\text { (www.unglobalcompact.org) }\end{array}$ & $\begin{array}{l}\text { It is a strategic policy } \\
\text { initiative for businesses that } \\
\text { are committed to aligning } \\
\text { their operations and strategies } \\
\text { with ten universally accepted } \\
\text { principles in the areas of } \\
\text { human rights, labor, } \\
\text { environment and } \\
\text { anticorruption. }\end{array}$ & $\begin{array}{l}\text { Mainstream the ten principles } \\
\text { in business activities around the } \\
\text { world. Catalyze actions in } \\
\text { support of broader UN goals, } \\
\text { including the Millennium } \\
\text { Development Goals (MDGs). }\end{array}$ & $\begin{array}{l}\text { Human rights, } \\
\text { Labor, } \\
\text { Environment and } \\
\text { Anticorruption. }\end{array}$ \\
\hline & $\begin{array}{l}\text { OECD Guidelines for } \\
\text { Multinational Enterprises } \\
\text { (www.oecd.org) }\end{array}$ & $\begin{array}{l}\text { Promote policies that will } \\
\text { improve the economic and } \\
\text { social well-being of people } \\
\text { around the world. }\end{array}$ & $\begin{array}{l}\text { Recommend policies designed } \\
\text { to make the lives of ordinary } \\
\text { people better. }\end{array}$ & $\begin{array}{l}\text { Human Rights, } \\
\text { Environment, } \\
\text { Combating } \\
\text { Bribery, } \\
\text { Competition and } \\
\text { Taxation }\end{array}$ \\
\hline & $\begin{array}{l}\text { Tripartite declaration of } \\
\text { principles concerning } \\
\text { multinational enterprises } \\
\text { and social policy } \\
\text { (ILO, 2006) }\end{array}$ & $\begin{array}{l}\text { Offer the principles laid } \\
\text { down in this universal } \\
\text { instrument, offer guidelines } \\
\text { to MNEs, governments, and } \\
\text { employers' and workers' } \\
\text { organizations in such areas as } \\
\text { employment, training, } \\
\text { conditions of work and life, } \\
\text { and industrial relations. }\end{array}$ & $\begin{array}{l}\text { To increase adherence to the } \\
\text { Declaration by all concerned, } \\
\text { would contribute to a climate } \\
\text { more conducive to economic } \\
\text { growth and social development }\end{array}$ & $\begin{array}{l}\text { Labor } \\
\text { Human Rights }\end{array}$ \\
\hline $\begin{array}{l}\text { Process guidelines: } \\
\text { Provide guidance on } \\
\text { measurement, } \\
\text { communication and } \\
\text { assurance }\end{array}$ & $\begin{array}{c}\text { GRI } \\
(\mathrm{GRI}, 2012)\end{array}$ & $\begin{array}{l}\text { It is a non-profit organization } \\
\text { that works towards a } \\
\text { sustainable global economy } \\
\text { by providing sustainability } \\
\text { reporting guidance. }\end{array}$ & $\begin{array}{l}\text { To make sustainability } \\
\text { reporting standard practice by } \\
\text { providing guidance and support } \\
\text { to organizations. }\end{array}$ & $\begin{array}{l}\text { Environment } \\
\text { Social } \\
\text { Responsibility }\end{array}$ \\
\hline \multirow{4}{*}{$\begin{array}{c}\text { Management } \\
\text { systems: Provide } \\
\text { detailed and } \\
\text { integrated guidance } \\
\text { on how to integrate } \\
\text { the management of } \\
\text { social and } \\
\text { environmental issues } \\
\text { with firm operations }\end{array}$} & $\begin{array}{c}\text { ISO } 26000 \\
\text { (ISO, 2010a) }\end{array}$ & $\begin{array}{c}\text { ISO } 26000 \text { is an ISO } \\
\text { International Standard giving } \\
\text { guidance on SR for business } \\
\text { organizations and public } \\
\text { sector organizations of all } \\
\text { types. }\end{array}$ & $\begin{array}{l}\text { To help all types of organizatior } \\
\text { manner by providing guidance } c\end{array}$ & $\begin{array}{c}\text { Social } \\
\text { Responsibility }\end{array}$ \\
\hline & $\begin{array}{l}\text { AA1000 Framework } \\
\text { (AccountAbility, 2008) }\end{array}$ & $\begin{array}{l}\text { Developed to help } \\
\text { organizations build their } \\
\text { accountability and social } \\
\text { responsibility through quality } \\
\text { social and ethical accounting, } \\
\text { auditing and reporting. }\end{array}$ & $\begin{array}{l}\text { It addresses the need for } \\
\text { organizations to integrate their } \\
\text { stakeholder engagement } \\
\text { processes into their daily } \\
\text { activities }\end{array}$ & Social and Ethical \\
\hline & $\begin{array}{l}\text { ISO } 14001 \\
\text { (ISO, 2007) }\end{array}$ & $\begin{array}{l}\text { ISO } 140001 \text { gives the generic } \\
\text { requirements for an } \\
\text { environmental management } \\
\text { system. }\end{array}$ & $\begin{array}{l}\text { To provide a framework for a } \\
\text { holistic, strategic approach to } \\
\text { the organization's } \\
\text { environmental policy, plans } \\
\text { and actions. }\end{array}$ & Environment \\
\hline & $\begin{array}{l}\text { SA88000 } \\
(\text { SAI, 2008) }\end{array}$ & $\begin{array}{l}\text { It is an auditable certification } \\
\text { standard based on } \\
\text { international workplace } \\
\text { norms of International Labor } \\
\text { Organization (ILO) } \\
\text { conventions, the Universal } \\
\text { Declaration of Human Rights } \\
\text { and the UN Convention on } \\
\text { the Rights of the Child. }\end{array}$ & $\begin{array}{l}\text { Provide a standard based on } \\
\text { international human rights } \\
\text { norms and national labor laws. }\end{array}$ & Human rights \\
\hline
\end{tabular}


Table 2. GRI information principles.

\begin{tabular}{|c|c|c|}
\hline Principle & Definition & Explanation \\
\hline Materiality & $\begin{array}{l}\text { Financial factors, social and } \\
\text { economic, with an impact on } \\
\text { stakeholders. }\end{array}$ & $\begin{array}{l}\text { The relevant aspects and indicators are those } \\
\text { that can be considered important in reflecting } \\
\text { the social, environmental and economic } \\
\text { impacts of the organization or that influence } \\
\text { stakeholder decisions and, for these reasons, } \\
\text { potentially deserve to be included in the } \\
\text { report. }\end{array}$ \\
\hline $\begin{array}{l}\text { Participation of } \\
\text { stakeholders }\end{array}$ & $\begin{array}{l}\text { The informant organization } \\
\text { must identify its stakeholders } \\
\text { and describe in the report } \\
\text { how it has responded to their } \\
\text { reasonable expectations and } \\
\text { interests. }\end{array}$ & $\begin{array}{l}\text { Stakeholders may include individuals or } \\
\text { entities that have a financial relationship to } \\
\text { the organization (employees, shareholders, } \\
\text { suppliers) as well as those agents outside the } \\
\text { organization (the local community, society in } \\
\text { general). }\end{array}$ \\
\hline Sustainability context & $\begin{array}{l}\text { The informant organization } \\
\text { must submit its performance } \\
\text { within the broader context of } \\
\text { sustainability. }\end{array}$ & $\begin{array}{l}\text { This includes analyzing the performance of } \\
\text { the organization in the context of limits and } \\
\text { requirements imposed on environmental or } \\
\text { social resources at the sector, local, regional } \\
\text { or global levels. }\end{array}$ \\
\hline Completeness & $\begin{array}{l}\text { The coverage of indicators } \\
\text { and material aspects in the } \\
\text { report should be detailed } \\
\text { enough to reflect the social, } \\
\text { economic and environmental } \\
\text { impacts of the enterprise and } \\
\text { to allow stakeholders to } \\
\text { evaluate the performance of } \\
\text { the informant organization } \\
\text { during the period covered by } \\
\text { the report. }\end{array}$ & $\begin{array}{l}\text { The concept of completeness primarily } \\
\text { concerns the scope, degree of coverage and } \\
\text { time period covered. Completeness can also } \\
\text { refer to the information collection practices } \\
\text { and whether the reporting is reasonable and } \\
\text { appropriate. These aspects relate to the } \\
\text { accuracy of reporting. }\end{array}$ \\
\hline
\end{tabular}

Source: the Global Reporting Initiative (2006) 
Table 3. GRI quality principles.

\begin{tabular}{|c|c|c|}
\hline Principle & Definition & Explanation \\
\hline Balance & $\begin{array}{l}\text { Balance refers to the influences of } \\
\text { both positive and negative impacts } \\
\text { on the development of the } \\
\text { organization to form a reasonable } \\
\text { judgment on the general } \\
\text { development of the organization. }\end{array}$ & $\begin{array}{l}\text { This principle seeks to establish an unbiased } \\
\text { perspective on the development of an informant } \\
\text { organization, avoiding the selective reporting of } \\
\text { information that might improperly influence a } \\
\text { decision or judgment made by a reader of the } \\
\text { report. }\end{array}$ \\
\hline Comparability & $\begin{array}{l}\text { The information given should be } \\
\text { presented in a way that allows } \\
\text { interested parties to analyze } \\
\text { experimental changes made by the } \\
\text { organization over time within an } \\
\text { organization and to compare the } \\
\text { information between organizations. }\end{array}$ & $\begin{array}{l}\text { Comparisons are essential to evaluating } \\
\text { development. An interested party using a report } \\
\text { should be able to compare information on the } \\
\text { economic, environmental and social development } \\
\text { of the organization with their previous } \\
\text { development and with that of other organizations. } \\
\text { This principle seeks to maintain consistency in the } \\
\text { methods used to calculate the data, in the } \\
\text { preparation of the report and the description of the } \\
\text { methods used in the preparation of the information } \\
\text { contributing to comparisons within and between } \\
\text { organizations. }\end{array}$ \\
\hline Accuracy & $\begin{array}{l}\text { The information in the report must } \\
\text { be accurate and detailed enough to } \\
\text { enable interested parties to } \\
\text { evaluate the development of the } \\
\text { organization. }\end{array}$ & $\begin{array}{l}\text { Answers with respect to economic, environmental } \\
\text { and social indicators can range from qualitative to } \\
\text { measurably qualitative. For example, the accuracy } \\
\text { of qualitative information is determined by the } \\
\text { clarity, detail, completeness and balance in an } \\
\text { answer. The accuracy of the quantitative } \\
\text { information depends on the methods used to } \\
\text { recover, compile and analyze data. }\end{array}$ \\
\hline $\begin{array}{l}\text { Regular } \\
\text { recurrence }\end{array}$ & $\begin{array}{l}\text { The information should be } \\
\text { presented on time following a } \\
\text { periodic calendar in such a way } \\
\text { that an interested party can make } \\
\text { decisions using accurate and up-to- } \\
\text { date information. }\end{array}$ & $\begin{array}{l}\text { The utility of information depends on the } \\
\text { timeliness with which it is provided, allowing an } \\
\text { interested party to effectively integrate the } \\
\text { information when making a decision. This } \\
\text { requires that regular updates to the information be } \\
\text { provided to allow for informed comparisons } \\
\text { during the reporting periods relevant to different } \\
\text { interested parties. }\end{array}$ \\
\hline Clarity & $\begin{array}{l}\text { The information should be } \\
\text { presented in a way that is } \\
\text { understandable and accessible to } \\
\text { all of the interested parties who } \\
\text { may access and use the report. }\end{array}$ & $\begin{array}{l}\text { The report presents the information (in written } \\
\text { form or in some other medium) in a way that is } \\
\text { understandable, accessible, and usable by the } \\
\text { parties that are interested in the organization. The } \\
\text { graphs and charts representing the data are } \\
\text { consolidated and supplement the information in } \\
\text { the report to make it accessible and } \\
\text { understandable. }\end{array}$ \\
\hline Reliability & $\begin{array}{l}\text { The information and procedures in } \\
\text { the preparation of the report should } \\
\text { be compiled, registered and } \\
\text { analyzed, and presented in a way } \\
\text { that they can be used in } \\
\text { assessments and help to establish } \\
\text { the quality and the accuracy of the } \\
\text { information. }\end{array}$ & $\begin{array}{l}\text { The confidence interested parties have in a report } \\
\text { can be strengthened by providing evidence for the } \\
\text { veracity of its contents and by the care and } \\
\text { thoroughness with which it has been compiled. } \\
\text { The information and data included in the report } \\
\text { should be supported by documents and internal } \\
\text { controls that can be verified by third parties. }\end{array}$ \\
\hline
\end{tabular}

Source: the Global Reporting Initiative (2006) 
Table 4. GRI reports by geographical areas and at a worldwide scale.

\begin{tabular}{|l|c|c|c|c|c|c|c|}
\hline & Africa & Asia & Europe & $\begin{array}{c}\text { Latin } \\
\text { America }\end{array}$ & $\begin{array}{c}\text { North } \\
\text { America }\end{array}$ & Oceania & $\begin{array}{c}\text { Total } \\
\text { World }\end{array}$ \\
\hline 1999 & 0 & 1 & 0 & 0 & 5 & 0 & 6 \\
\hline 2000 & 3 & 7 & 1 & 1 & 2 & 1 & 15 \\
\hline 2001 & 1 & 1 & 15 & 2 & 6 & 9 & 34 \\
\hline 2002 & 8 & 3 & 22 & 9 & 31 & 12 & 85 \\
\hline 2003 & 2 & 3 & 54 & 5 & 31 & 10 & 105 \\
\hline 2004 & 22 & 8 & 115 & 9 & 47 & 14 & 215 \\
\hline 2005 & 23 & 29 & 180 & 17 & 50 & 23 & 322 \\
\hline 2006 & 25 & 39 & 223 & 51 & 70 & 40 & 448 \\
\hline 2007 & 24 & 85 & 342 & 80 & 27 & 48 & 606 \\
\hline 2008 & 51 & 185 & 457 & 141 & 38 & 71 & 943 \\
\hline 2009 & 54 & 304 & 647 & 189 & 83 & 90 & 1,467 \\
\hline 2010 & 55 & 367 & 829 & 258 & 66 & 81 & 1,656 \\
\hline
\end{tabular}

Source: compiled from the Global Reporting Initiative database (2010). 


\section{Figures}

Figure 1. The logistic curve at the worldwide scale and of Europe, Asia and Latin America.
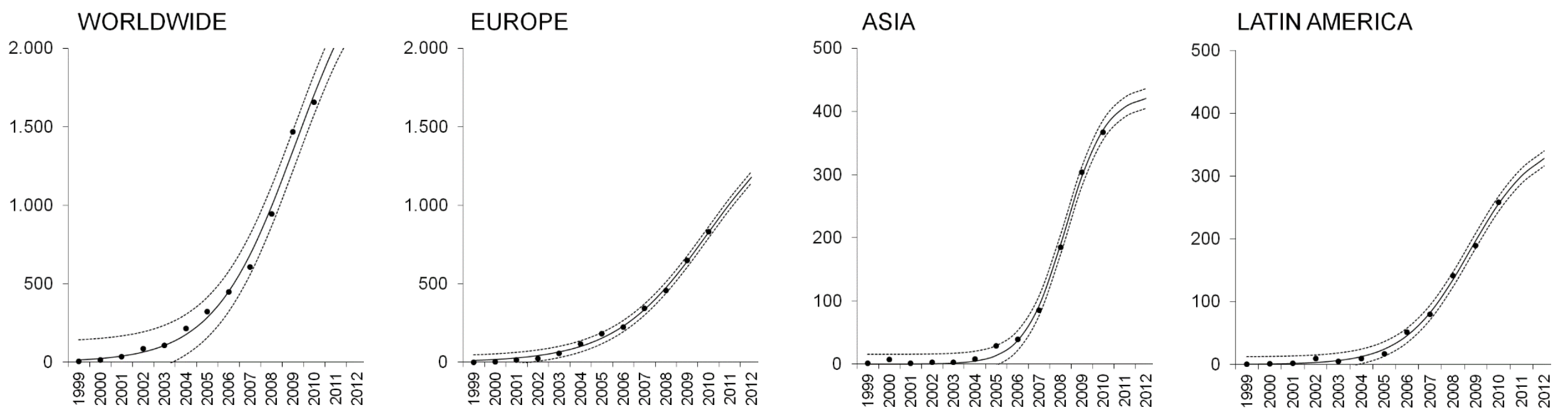

\begin{tabular}{|c|c|c|c|c|c|c|c|c|c|c|c|c|}
\hline & \multicolumn{3}{|c|}{ World } & \multicolumn{3}{|c|}{ Europe } & \multicolumn{3}{|c|}{ Asia } & \multicolumn{3}{|c|}{ Latin America } \\
\hline & Value & $\mathbf{L l}^{\mathrm{a}}$ & $\mathbf{U l}^{\mathrm{b}}$ & Value & $\mathbf{L l}^{\mathrm{a}}$ & $\mathbf{U l}^{\mathrm{b}}$ & Value & $\mathbf{L l}^{\mathrm{a}}$ & $\mathbf{U l}^{\mathrm{b}}$ & Value & $\mathbf{L l}^{\mathrm{a}}$ & $\mathbf{U l}^{\mathrm{b}}$ \\
\hline $\mathbf{N}_{0}$ & 13.3 & -0.7 & 27.3 & 10.6 & 5.0 & 16.3 & 0.0 & -0.1 & 0.1 & 0.3 & 0.0 & 0.8 \\
\hline $\mathbf{K}$ & $2,784.6$ & $1,490.1$ & $4,079.2$ & $1,638.6$ & 989.6 & $2,287.6$ & 428.6 & 385.2 & 471.9 & 361.5 & 285.7 & 437.2 \\
\hline $\mathbf{r}_{0}$ & .527 & .377 & .677 & .459 & .380 & .538 & 1.053 & .885 & 1.222 & .702 & .577 & .827 \\
\hline r squared & \multicolumn{3}{|c|}{.992} & \multicolumn{3}{|c|}{.997} & \multicolumn{3}{|c|}{.998} & \multicolumn{3}{|c|}{.997} \\
\hline
\end{tabular}

The dotted lines on both sides in the figures represent the lower and upper limits of the 95 percent confidence interval.

${ }^{a}$ The lower limit of the 95 percent confidence interval

$\mathrm{b}$ The upper limit of the 95 percent confidence interval

Source: compiled from the Global Reporting Initiative (2010) database. 
Figure 2. The evolution of GRI reports by activity sectors (only the top seven sectors in the 2010 ranking are shown).

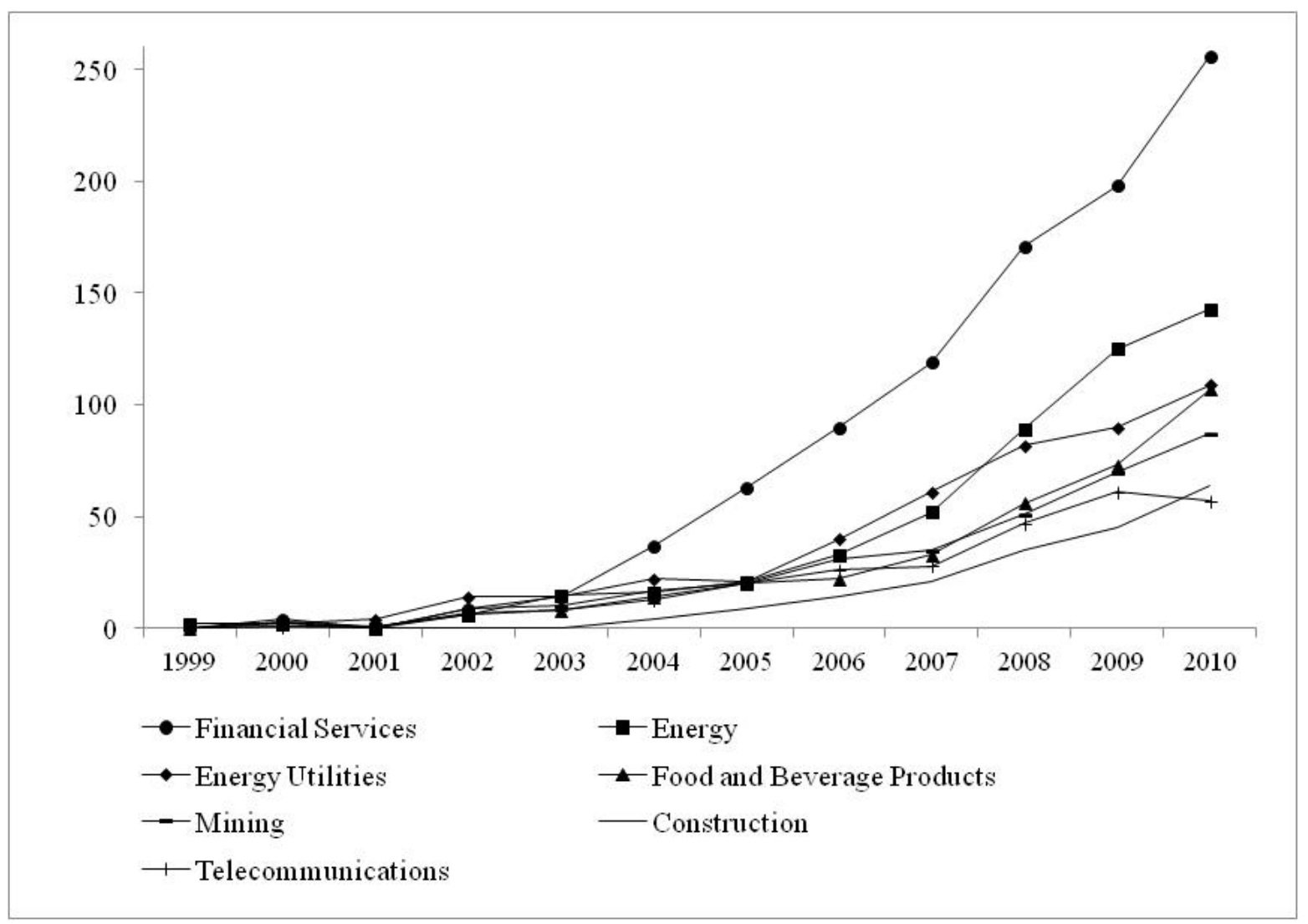


Figure 3: The evolution of the rankings by sector of economic activity as a proportion of the total number of GRI certifications.

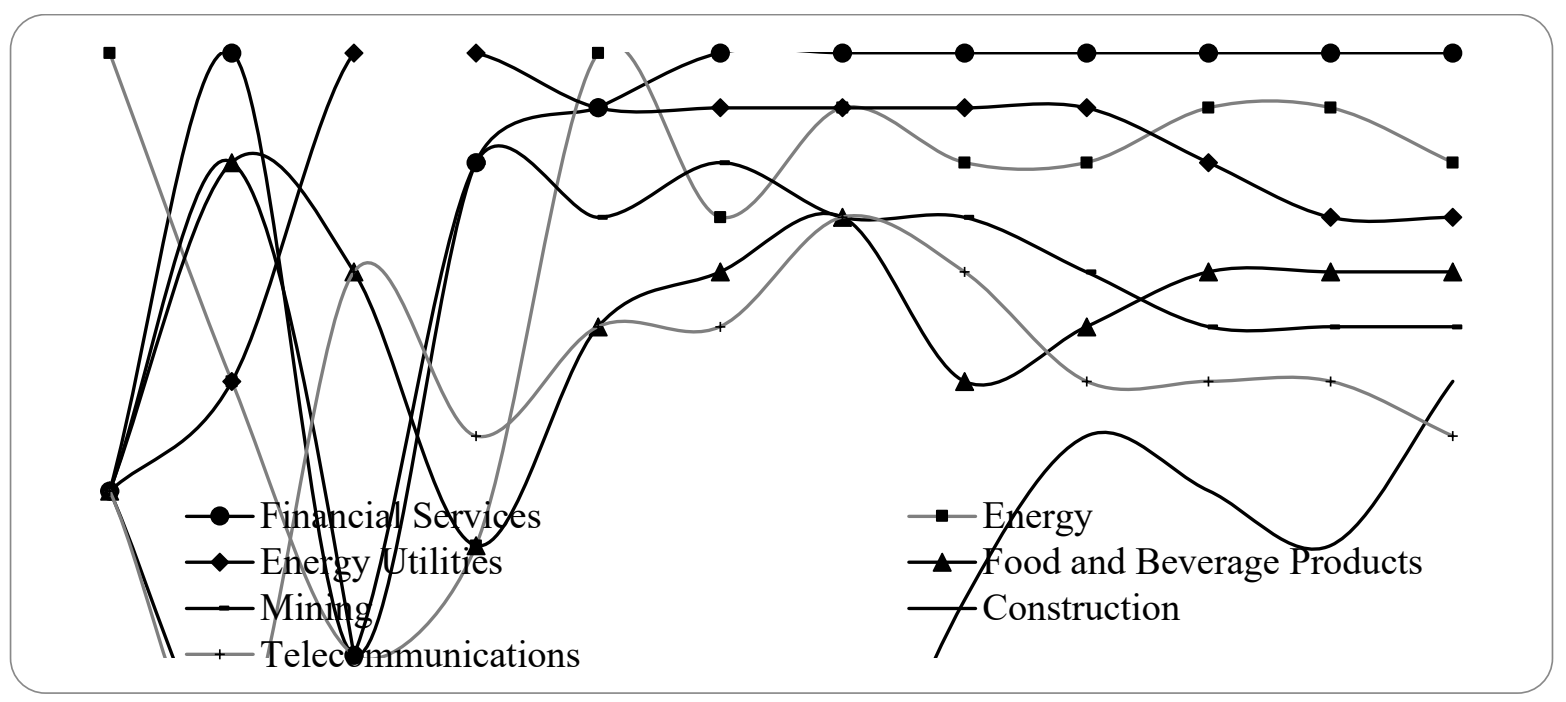


Figure 4: The evolution of the index of instability in the rankings of sectors in relation to the number of GRI reports.

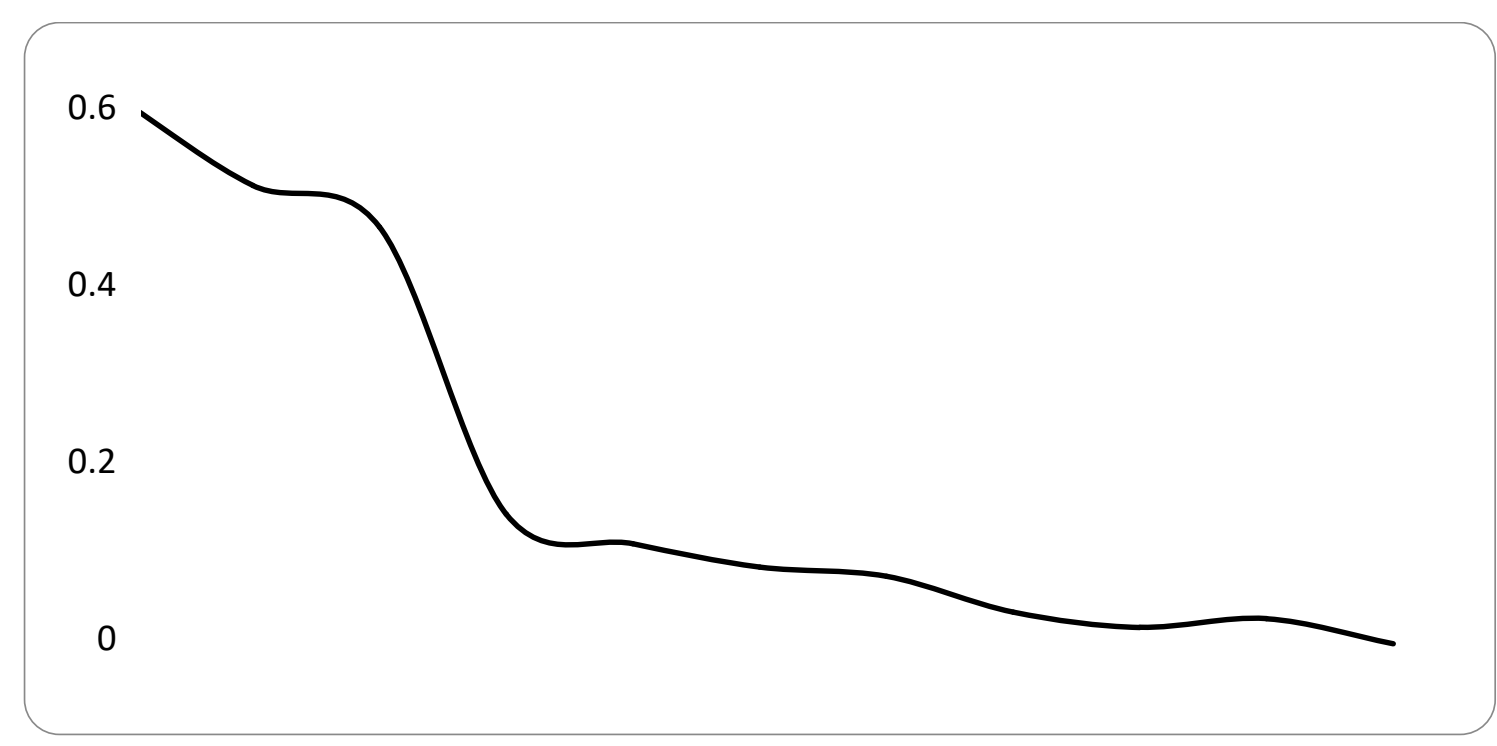


Figure 5. The evolution of the Herfindahl index in the sector rankings in relation to the number of GRI reports.

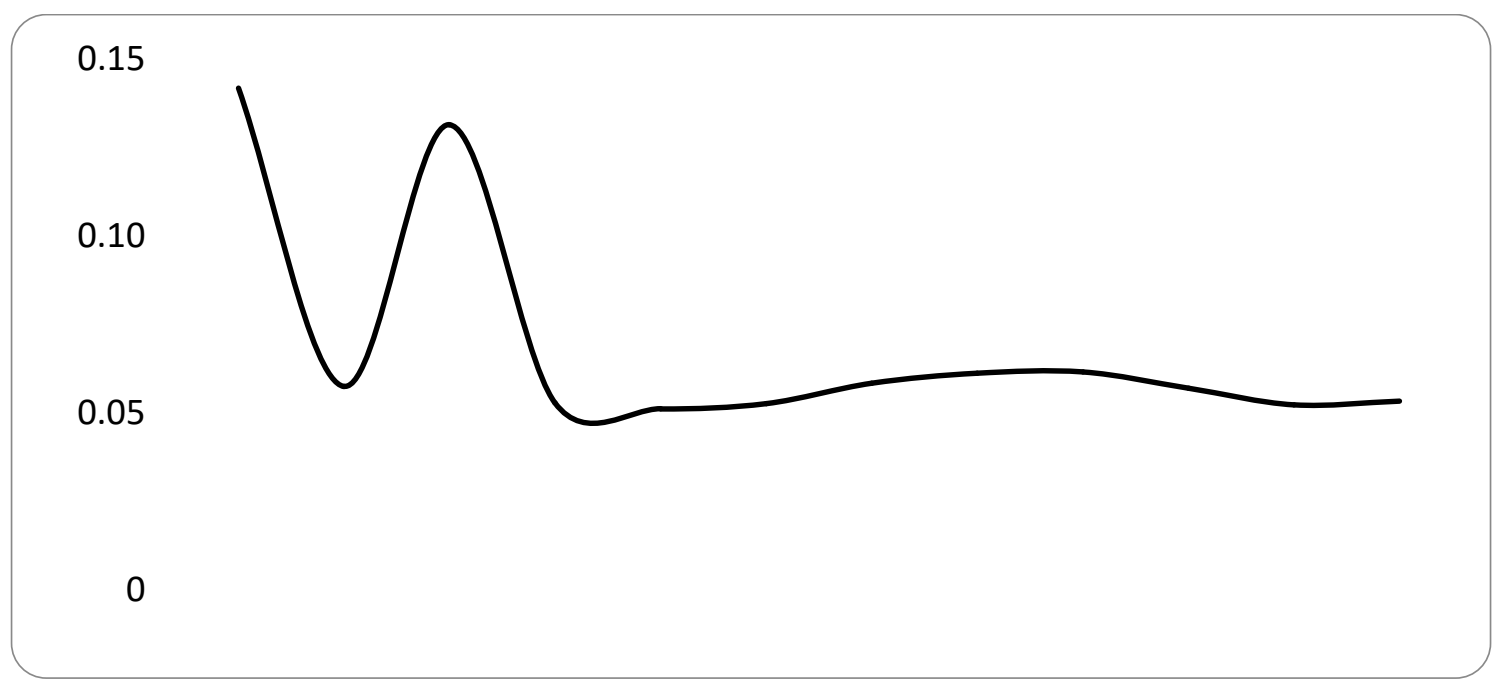

